J-ABDIPAMAS (Jurnal Pengabdian Kepada Masyarakat)

Vol. $3 \bullet$ No. $2 \bullet 2019$

ISSN : 2581-1320 (Print) ISSN : 2581-2572 (Online)

Homepage: http://ejurnal.ikippgribojonegoro.ac.id/index.php/J-ABDIPAMAS

\title{
PEMBERDAYAAN KARANG TARUNA HIMUBORA MELALUI PUPUK FERMENTATION DAN GRANULATION SYSTEM
}

\section{Vierina Beta Nurintan', Nita Ernawati², Rizki Dandy M. P. ${ }^{3}$, Fajar Pradana $^{4}$, Entry Widyawati Kusuma ${ }^{5}$}

1Fakultas Pertanian, Universitas Brawijaya. Email: Vierinabeta05@gmail.com

2Fakultas Pertanian, Universitas Brawijaya. Email: Nitata048@gmail.com

${ }^{3}$ Fakultas Pertanian, Universitas Brawijaya. Email: rizkidandy077@gmail.com

4Fakultas Pertanian, Universitas Brawijaya. Email: Pradanafajar83@gmail.com

5Fakultas Peternakan, Universitas Brawijaya. Email: entrywidyawati@gmail.com

\begin{abstract}
The problem in Bocek Krajan village is the presence of organic waste like vegetables and fruits leftover that are left to rot without any special treatment. In addition there is livestock manure waste like urine or feces and tofu water waste from the tofu processing industry that is close to the civil residence. That kind of things that cause foul odors and environmental pollution around the Bocek Krajan Village. This encourages training in the manufacture of fermentation and granuation fertilizer by involving HIMUBORA youth organizations to improve the productivity of youth organizations by implementing agrocomplex waste management systems through fermentation and granulation so as to realize sustainable agriculture and overcome environmental problems. The method used in this activity is a training method. The results of this activity are orbanic waste in the form of leftover vegetables and fruit, as well as waste water of tofu, and livestock manure can be used as liquid fertilizer and granules
\end{abstract}

Keywords: Waste, Fermentation, granuation

\section{ABSTRAK}

Permasalahan pada Desa Bocek Krajan yaitu adanya limbah organik seperti sisa sayur dan buah yang dibiarkan membusuk tanpa ada perlakuan khusus. Selain itu terdapat limbah kotoran ternak seperti urin atau feses dan limbah air tahu dari industri pengolahan tahu yang dekat dengan tempat tinggal warga. Hal-hal tersebut menimbulkan bau busuk dan pencemaran lingkungan sekitar Desa Bocek Krajan. Hal ini yang mendorong adanya kegiatan pelatihan pembuatan pupuk fermentation dan granuation dengan melibatkan pemuda karang taruna HIMUBORA guna meningkatkan produktifitas karang taruna dengan penerapan sistem pengelolaan limbah agrokompleks melalui fermentation dan granulation sehingga bisa mewujudkan suistainable agriculture serta mengatasi permasalahan lingkungan. Metode yang digunakan dalam kegiatan ini berupa metode pelatihan. Hasil dari kegiatan ini adalah limbah orbanik berupa sisa sayur dan buah, serta limbah air tahu, dan kotoran ternak dapat dimanfaatkan sebagai pupuk cair dan granul.

Kata Kunci: Limbah, Fermentation, granuation 


\section{PENDAHULUAN}

Sisa hasil kegiatan manusia baik pertanian, peternakan, dan kegiatan rumah tangga menghasilkan limbah. Limbah merupakan bahan organik atau anorganik yang tidak termanfaatkan lagi, sehingga dapat menimbulkan masalah serius bagi lingkungan jika tidak ditkelola dengan baik. Limbah dapat berasal dari berbagai sumber hasil buangan dari suatu proses produksi salah satunya limbah peternakan. Limbah tersebut dapat berasal dari rumah potong hewan, pengolahan produksi ternak, dan hasil dari kegiatan usaha ternak.

Desa Bocek merupakan salah satu desa di Kecamatan Karangploso merupakan salah satu kecamatan yang terletak di Kabupaten Malang, letaknya cukup strategis berada diantara perbatasan Kabupaten Malang dengan Kota Batu serta termasuk sentra penanaman cabai besar di Kabupaten Malang. Berdasarkan data monografi desa diketahui bahwa 93,4\% penduduk desa Tawangargo bekerja pada sektor pertanian sebanyak 4.100 orang, yaitu meliputi petani $(22,49 \%)$ dan buruh tani $(70,94 \%)$. Pekerjaan masyarakat yang paling besar adalah buruh tani. Hal ini mengindikasikan bahwa Desa Bocek mempunyai poteni pengembangan pertanian berkelanjutan. Namun, keadaan pertanian di desa Bocek tidak berjalan semestinya. Berbagai kegiatan warga mulai terhambat akibat sampah dan limbah yang tidak dikelola semestinya. Mulai pencemaran udara, air, dan lingkungan akibat limbah industri tahu, peternakan, dan sampah rumah tangga.

Pengelolaan limbah pada suatu kawasan berpenduduk memerlukan perlu penanganan secara terpadu. Hal ini tidak lepas dari peran masyarakat Desa Bocek terutama kaum muda dan mudi. Dimulai dengan meningkatnya kesadaran masyarakat untuk menjaga lingkungan menimbulkan pemikiran untuk mengolah limbah maupun kotoran ternak tersebut menjadi suatu produk yang lebih bermanfaat. Sampah maupun limbah tersebut dapat diminimalkan dengan menerapkan pengelolaan sampah yang terpadu (Integrated Solid Waste Management/ISWM), diantaranya waste to energy atau pengolahan sampah menjadi energi (Damanhuri, 2010). Kotoran ternak diolah dengan cara yang sesuai akan memberi nlai ekonomi tinggi seperti pemanfaatan kotoran sebagai bahan pembuatan pupuk padat dan pupuk cair. Begitu pula dengan limbah industri tahu serta rumah tangga. Berdasarkan permasalahan yang telah diuraikan diperlukan peran pemuda Desa Bocek guna sebagai generasi pelopor membangun Desa Bocek menjadi salah satu desa yang mendukung pertanian berkelanjutan. Penerapan progam pendampingan HIMUBORA (Himpunan Muda-Mudi Bocek Raya) untuk 
mengelola sampah maupun limbah menjadi pupuk organik yang dapat digunakan mendukung budidaya tanaman berasaskan pertanian berlanjut.

\section{METODE PELAKSANAAN}

Kegiatan Pelatihan ini dilaksanakan dalam waktu 5 bulan mulai dari April-Agustus 2019 dengan uraian kegiatan mulai dari persiapan dengan pembuatan modul dan persiapan alat bahan, sosialisai, pelaksanaan program, pendampingan kegiatan, dan monitoring evaluasi pelatihan. Tempat pelaksanaan program ini berada di Desa Bocek Krajan RT/RW 07/04 Kecamatan Karangploso Kabupaten Malang.

\section{HASIL DAN PEMBAHASAN}

Pelaksanaan pelatihan pembuatan pupuk ini dimulai dari tahap persiapan yang dimulai dari pembuatan modul. Modul yang dibuat akan berisi mengenai materi pemanfaatan limbah agrokompleks terutama dalam tahapan pembuatan POC (pupuk organik cair) dan POG (pupuk organik granul), serta pengaplikasiannya untuk pertanian komoditas sayur. Modul ini digunakan untuk memberikan informasi mengenai sistem pemanfaatan limbah pertanian dan agrokompleks. Modul akan diberikan kepada pemuda pemudi karang taruna HIMUBORA (Himpunan muda mudi Bocek Raya) pada saat sosialisasi dan penyuluhan berlangsung.

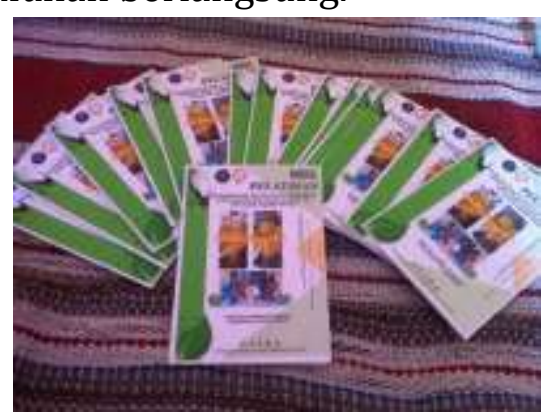

\section{Gambar 1. Modul untuk Pelatihan}

Langkah selanjutnya adalah persiapan pelaratan dan bahan. Peralatan yang digunakan dalam pelaksanaan program adalah bak penampung dengan tinggi $50 \mathrm{~cm}$ dan diameter $150 \mathrm{~cm}$ sebanyak 7 buah, mesin Granulator, plastik trashbag, pisau, selang, ember plastik, zak, nampan, oven, dan sekop. Sedangkan bahan yang dipergunakan adalah limbah sayur organik, feses kambing dan sapi, dedak, EM4, Molases dan air. 


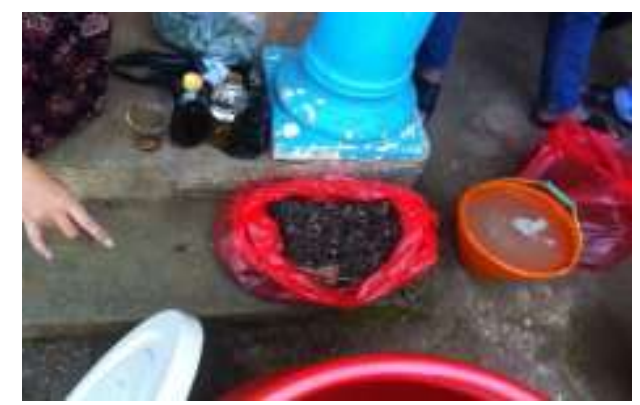

\section{Gambar 2. Persiapan Alat dan Bahan}

Setelah persiapan dilaksanakan, selanjutnya pelaksanakan kegiatan. Kegiatan ini diawali dengan forum group discussion. Tahap ini digunakan sebagai pengenalan program inovasi dan teknologi yang diterapkan sehingga akan menambah pemahaman tentang kegiatan yang dilakukan. Kegiatan sosialisasi dilakukan di Gubuk Baca milik karang taruna HIMUBORA. Sosialisasi dilakukan kepada pemuda karang taruna, dan masyarakat desa. Kegiatan ini menjelaskan mengenai alur kegiatan pengabdian secara garis besar kepada peserta. Bagaimana teknis dan eksekusinya, kelemahan atau resiko, dan juga profit serta keuntungan yang didapatkan. Forum Discussion ini dihadiri oleh 20 masyarakat yang terdiri dari 15 anggota karang taruna dan 5 masyarakat sekitar bykan anggota karang taruna.

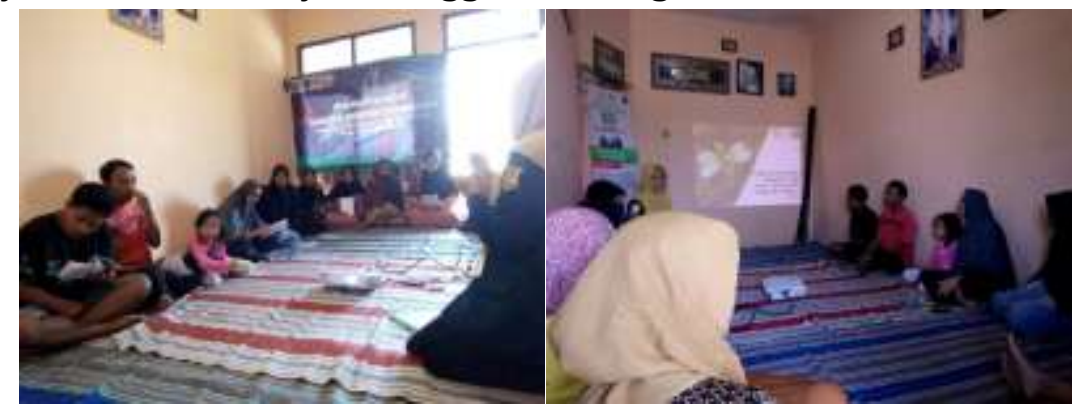

Gambar 3. Kegiatan Forum Discussion

Pada kegiatan forum discusion juga diadakan pengisian kuisioner yang terkait dengan pengetahuan dasar cara penanganan limbah di lingkungan sekitar.

Table 1. Rekap Hasil Pengisian Kuisioner

\begin{tabular}{lc}
\hline \multicolumn{1}{c}{ Indikator } & Presentase \\
\hline Apakah di tempat anda ada sampah? & $100 \%$ \\
\hline Apakah anda tahu cara pengolahan sampah organik? & $50 \%$ \\
\hline Apakah di tempat anda tinggal terdapat tempat pembuangan akhir? & $50 \%$ \\
\hline Apakah di desa tempat anda tinggal sudah melakukan pengolahan sampah & $25 \%$ \\
\hline
\end{tabular}




\begin{tabular}{lc}
\hline organik secara baik? & \\
\hline Seberapa penting pengolahan sampah organik menurut anda? & $100 \%$ \\
\hline Apakah anda sudah memilah sampah organik dan anorganik? & $20 \%$ \\
\hline Apakah anda menanam tanaman lahan pekarangan rumah/lahan lainnya? & $75 \%$ \\
\hline Apakah anda pernah menggunakan pupuk organik? & $40 \%$ \\
\hline Menurut anda apakah pupuk organik efektif terhadap tanaman anda? & $20 \%$ \\
\hline $\begin{array}{l}\text { Apakah menurut anda sampah organik sisa rumah tangga/industri } \\
\text { tahu/peternakan bisa dimanfaatkan menjadi pupuk organic? }\end{array}$ & $40 \%$ \\
\hline & $\mathbf{5 2 \%}$
\end{tabular}

Berdasarkan hasil pengisian kuisioner menunjukkan bahwa 100\% atau 20 responden menyatakan bahwa terdapat sampah di tempat mereka tinggal. 50\% atau 10 responden menyatakan tahu cara pengolahan sampah organik dan menyatakan bahwa terdapat tempat pembuanagan akhir, sedangkan sisanya belum tau cara pengolahan sampah organik dan menyatakan bahwa tidak terdapat tempat pembuanagn akhir. Sebesar 25\% atau 5 responden menyatakan bahwa di desa tempat tinggal mereka sudah melakukan pengolahan sampah organik secara baik namun $15 \%$ responden menyatakan tidak atau belum melakukan pengolahan sampah organik secara baik. Seluruh responden menyatakan bahwa pengolahan sampah organik penting untuk dilaksanakan, namun masih $20 \%$ atau 4 responden yang melakukan pemilahan sampah organik dan anorganik, serta masih $40 \%$ atau 8 responden yang pernah menggunakan pupuk organik dan $20 \%$ diantaranya atau 4 responden menyatakan efektif terhadap pertumbuhan tanaman. berdasarkan kuisioner yang telah dibagikan, terdapat 15 dari 20 responden atau $75 \%$ mempunyai tanaman di lahan pekarangan rumah atau lahan dan hanya $40 \%$ atau 8 responden yang mengetahu bahwa sampah organik sisa rumah tangga/industri tahu/peternakan bisa dimanfaatkan menjadi pupuk organik. Sehingga diperoleh rata-rata mencapai 52\% dan kegiatan pelatihan ini akan menjadi solusi yang tepat untuk mengatasi permasalahan di Desa Boce Krajan.

Kegiatan selanjatunya adalah tahap pelaksanaan. Kegiatan pelatihan dengan pemanfaatan limbah pertanian maupun peternakan secara kompleks menjadi pupuk cair dan granul dengan penambahan berbagai bahan pendukung untuk meningkatkan kandungan pupuk sehingga mampu digunakan untuk meningkatkan zat hara tanah pada lahan pertanian sayuran dimana melibatkan unit rumah tangga masyarakat desa, peternakan sapi perah, peternakan kambing, limbah pertanian, dan pabrik tahu rumahan. 


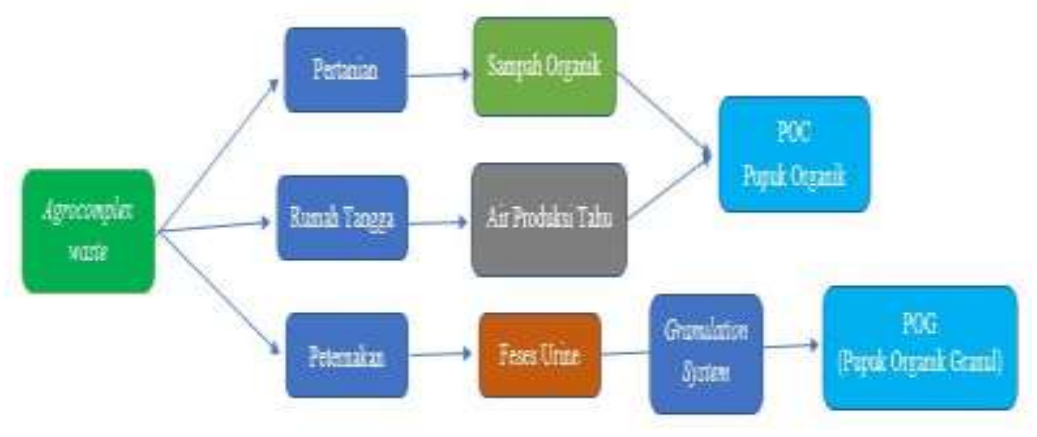

Gambar 4. Skema Konsep Pelatihan

Dengan pengelolaan limbah maksimal sehingga dapat mewujudkan sistem pertanian berbasis zero waste. Adapun metode pelaksanaan pelatihan adalah dimulai dari tahap pelatihan awal. Tahap ini dimulai dengan Pelatihan Pembuatan Pupuk Organik Cair (POC). Pupuk organik merupakan bahan yang ditambahkan ke tanaman sebagai penambah nutrisi. Penggunaaan pupuk organik saat ini sangat jarang dilakukan oleh petani karena harga yang relatif mahal serta pembuatan yang rumit. Selain itu pupuk organik jarang dijual di pasaran. Pemanfaatan limbah organik dari sisa sayuran dan limbah air tahu bisa diaplikasikan menjadi pupuk organik cair (POC), hal tersebut sesuai dengan Saenab S. et al. (2018), bahwa limbah cair tahu dapat dijadikan pupuk organik cair karena mengandung nutrisi yang dibutuhkan oleh tanaman pada masa vegetatif. Limbah sayuran dan limbah air tahu difermentasi menggunakan EM4 (Effective Microorganism 4) dan molases. Penggunaan EM4 berfungsi sebagai bakteri pengurai serta molases sebagai media pertumbuhan bakteri. Hal tersebut sesuai dengan Siswati N. D. et. al. (2009) bahwa EM4 dapat merangsang pertumbuhan mikroorganisme yang menguntungkan seperti bakteri pengikat nitrogen, pelarut phosphat, dsb. Yang dapat membantu pengomposan. Setelah POC telah mengalami fermentasi, tahap selanjutnya dilakukan penyaringan dan pengemasan. Sisa ampas dari pupuk cair akan dicampurkan sebagai bahan POG (Pupuk Organik Granul).

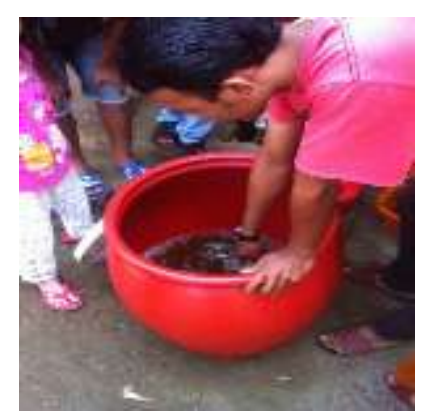

Gambar 5. Pembuatan POC 
Kegitan dilanjutkan dengan Pelatihan Pembuatan Pupuk Organik Granul (POG) Pupuk organik berbasis granulasi merupakan suatu teknologi mengenai pupuk organik berbahan dasar dari feses kambing maupun sapi yang dibentuk seperti butiran-butiran granul yang memiliki keunggulan pada masa simpan yang lebih lama dibanding dengan pupuk bokashi. Hal tersebut sesuai dengan Sahwan et al. (2011), bahwa pupuk organik granul merupakan pupuk yang melewati serangkaian proses panjang mulai dari pencampuran bahan, proses granulasi, pengeringan, pendinginan, dan penyaringan sehingga berbentuk butiran-butiran atau granul. Selain itu kandungan dari pupuk granul juga akan meningkatkan unsur hara tanah pada lahan pertanian sehingga secara tidak langsung mampu menekan biaya pembelian pupuk pada pertanian sayuran. Pupuk dibuat dari bahan-bahan yang tidak menimbulkan residu dibanding pupuk kimia sehingga kualitas sayuran dapat lebih baik. Bahan-bahan yang digunakan dalam pelatihan pembuatan pupuk granul ini adalah : feses sapi, feses kambing, ampas POC, EM4, molases, dan air. Tahap awal pembuatan POG adalah pengomposan feses dan ampas POC. Proses pengomposan akan menguraikan pupuk siap untuk digunakan oleh tanaman. Tahapan selanjutnya adalah proses granulasi lalu pengemasan.

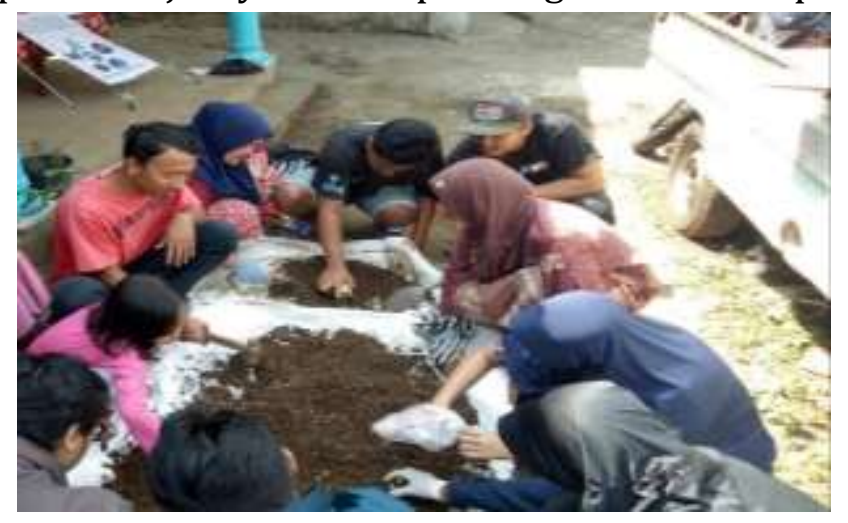

Gambar 6. Pembuatan POG

Setelah tahap pelatihan selesai dilanjutkan dengan tahap pelatihan lanjutan yang diawali dengan pelatihan penanganan produk pupuk. Pelatihan pengemasan dan pemasaran dilakukan untuk memberikan nilai lebih dan daya tarik konsumen terhadap produk pupuk sehingga meningkatkan permintaan pembelian yang nantinya dapat dipasarkan guna meningkatkan profit serta mengurangi volume limbah sayuran disekitar desa. Hal tersebut sesuai dengan Susetyarsi (2012), bahwa pengemasan termasuk dalam strategi pemasaran khususnya strategi produk dengan tujuan menarik perhatian konsumen dan memberi kesan bahwa prosuk tersebut bermutu, berkualitas, dan layak untuk dibeli. Pengemasan terdiri dari 2 ukuran untuk POC (Pupuk Organik Cair) yaitu ukuran 500ml dan 1000ml. Sedangkn untuk POG (Pupuk Organik Granul) terdiri dari 1 ukuran yaitu 5kg. 


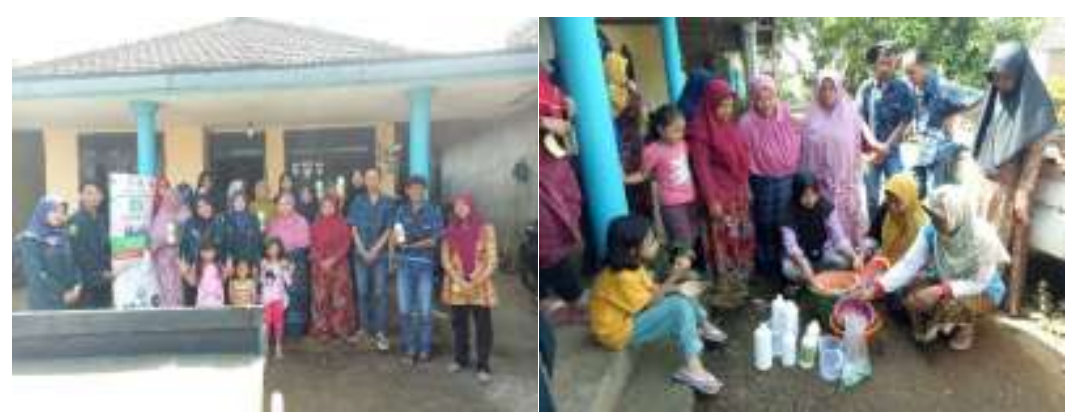

Gambar 7. Pelatihan Pengemasan dan Pemasaran

Kegiatan terakhir adalah pelatihan kewirausahaan dan manajemen pelatihan. Jiwa kewirausahaan dengan memanfaatkan potensi SDA secara maksimal melalui pertanian berbasis zero waste merupakan tujuan dalam program ini. Tim juga akan mendampingi dalam proses pemasaran, desain kemasan, maupun akun sosial media. Memanajemen suatu program usaha adalah hal yang penting juga, hal ini terkait bagaimana cara membuat para pemuda tetap konsinten dan terus berkelanjutan dalam menjalankan pelatihan. Melatih manajemen waktu dan tenaga kerja antara pengolahan limbah pertanian, pembuatan pupuk cair organik, pembuatan pupuk granul dan pemasaran pupuk sehingga pemuda karang taruna akan lebih berperan aktif dalam memanajemen dan keberlanjutan program dapat terjamin.

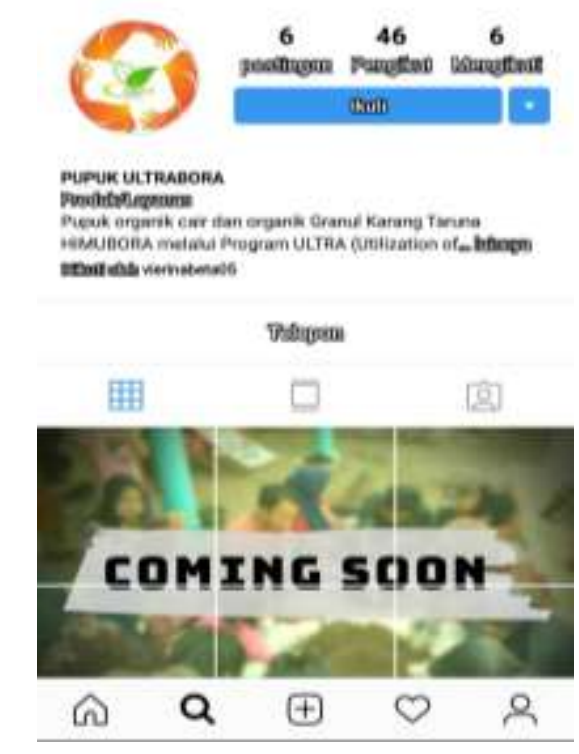

Gambar 8. Akun Instagram untuk Keberlanjutan

Setelah selesai menjalankan semua rangkaian pelatihan, pengisisan kuisioner juga dilakukan untuk mengetahui tingkat keberhasilan pelatihan. Berikut merupakan hasil pengisian kuisioner setelah dilakukan pelatihan kepada pemuda karang taruna HIMUBORA. 
Table 2. Hasil Pengisian Kuisioner Setelah Pelatihan.

\begin{tabular}{lc}
\hline \multicolumn{1}{c}{ Indikator } & Presentase \\
\hline Apakah di tempat anda ada sampah? & $100 \%$ \\
\hline Apakah anda tahu cara pengolahan sampah organik? & $100 \%$ \\
\hline Apakah di tempat anda tinggal terdapat tempat pembuangan akhir? & $100 \%$ \\
\hline $\begin{array}{l}\text { Apakah di desa tempat anda tinggal sudah melakukan pengolahan sampah } \\
\text { organik secara baik? }\end{array}$ & $75 \%$ \\
\hline Seberapa penting pengolahan sampah organik menurut anda? & $100 \%$ \\
\hline Apakah anda sudah memilah sampah organik dan anorganik? & $90 \%$ \\
\hline Apakah anda menanam tanaman lahan pekarangan rumah/lahan lainnya? & $100 \%$ \\
\hline Apakah anda pernah menggunakan pupuk organik? & $100 \%$ \\
\hline Menurut anda apakah pupuk organik efektif terhadap tanaman anda? & $75 \%$ \\
\hline $\begin{array}{l}\text { Apakah menurut anda sampah organik sisa rumah tangga/industri } \\
\text { tahu/peternakan bisa dimanfaatkan menjadi pupuk organic? }\end{array}$ & $100 \%$ \\
\hline
\end{tabular}

Berdasarkan hasil dari pengisian kuisioner diatas dapat diperoleh hasil bahwa secara umum kegiatan pelatihan ini berjalan dengan baik dan dapat mengatasi permasalahan Desa Bocek mengenai pencemaran lingkungan limbah air tahu, limbah organik seperti sisa sayur dan buah, serta limbah peternakan seperti feses dan urin hewan ternak masyarakat sekitar dengan menjadikan pupuk cair dan granul. Hal tersebut terlihat dari rata-rata persentase pengisian kuisioner setelah pelatihan sebesar 94\%, yang artinya mengalami peningkatan sebesar $42 \%$ dengan prosentase awal sebelum pelatihan mencapai 52\%. Untuk keberlanjutan dari pelatihan ini maka diperlukan kerjasama antara pemerintah, pelaku industri tahu, dan masyarakat sekitar. Hal tersebut sesuai dengan Tahir M. (2015) bahwa untuk keberlanjutan dalam Good Governance harus menyentuh 3 pihak yaitu pemerintah, pihak dunia usaha atau penggerak ekonomi, dan masyarakat sipil.

Setalah kegitan berakhir selanjutnya dilakukakn monitoring dan evaluasi yang bertujuan untuk melihat tingkat keberhasilan pelatihan pembuataan pupuk yang telah diterapkan serta melihat konsistensi pemuda karang taruna terkait program yang dicanangkan. Keberhasilan kegiatan ini dilihat melalui analisis kendala, peluang, kekuatan, dan kelemahan program dengan diskusi bersama pimpinan karang taruna. Kegiatan monitoring dan evaluasi dilakukan setiap 2 minggu sekali dengan cara bermusyawarah atau berdiskusi di rumah pimpinan karang taruna. Apabila terdapat kendala teknis akan dikonsultasikan dengan dosen pembimbing.

\section{SIMPULAN}

Berdasarkan pelatihan yang telah dilakukan maka dapat diambil kesimpulan bahwa limbah organik berupa sisa sayur dan buah, limbah 
peternakan, dan limbah air tahu dapat dimanfaatkan menjadi pupuk cair dan pupuk granul. Kegiatan pelatihan ini menjadikan mitra dapat mengetahui, memahami, dan dapat mempraktikan langsung dalam membuat pupuk dari limbah sayur, buah, kotoran ternak, dan limbah air tahu.

\section{UCAPAN TERIMA KASIH}

Ucapan terima kasih kami sampaikan kepada Ibu Dwi Retnoningsih SP., MP., MBA. Selaku dosen pembimbing, Bapak Titis selaku Ketua Karang Taruna HIMUBORA atas izin dan bantuannya selama kegiatan pelatihan, serta tim, masyarakat, dan Karang Taruna HIMUBORA atas kerjasama dan bantuannya selama kegiatan pelatihan.

\section{DAFTAR RUJUKAN}

Damanhuri E. (2010). Pengelolaan Sampah. Jurusan Teknik Lingkungan. Bandung (ID): ITB.

Dinas Kebudayaan dan Pariwisata Kabupaten Malang. (2006). Konsep Pengembangan Desa Wisata. Malang.

Saenab S., M. H. I. Al Muhdar dan F. Rohman. (2018). Pemanfaatan Limbah Cair Industri Tahu Sebagai Pupuk Organik Cair (POC) Guna Mendukung Program Lorong Garden (Longgar) Kota Makassar. Prosiding Seminar Nasional Megabiodiversitas Indonesia. 9 April 2018.

Sahwan, Firman L., Wahyono S., Suryanto, F,. (2011). Evaluasi Populasi Mikroba Fungsional Pada Pupuk Organik Kompos (POK) Murni Dan Pupuk Organik Granul (POG) Yang Diperkaya Dengan Pupuk Hayati. Jurnal Teknologi Lingkungan Vol. 12. No. 2.

Siswati N. D., Herwindo T., dan Puguh W. E. S. (2009). Kajian Penambahan Effective Microoganisms Pada Proses Dekomposisi Limbah Padat Industri Kertas. Buana Sains.

Susetyasari. (2012). Kemasan Produk Ditinjau Dari Bahan Kemasan, Bentuk Kemasan Dan Pelabelan Pada Kemasan Pengaruhnya Terhadap Keputusan Pembelian Pada Produk Minuman Mizone Di Kota Semarang. Jurnal Stie Semarang. Vol. 4. No. 3.

Tahir, M. (2015). Good Urban Governance: Peran Pemerintah dalam Pembangunan Wilayah Kecamatan di Kota Makassar. Government: Jurnal Ilmu Pemerintahan. Vol. 8, No. 1, (9-15). 